\title{
CADÊNCIA, DECADÊNCIA, RECADÊNCIA: O TROPICALISMO E O SAMBA-F̂ENIX
}

\author{
Marcos Silva \\ Depto. de História - FFLCH/USP
}

O livro Tropicalismo - Decadência bonita do samba, de Pedro Alexandre Sanches, contém muitas contribuições para o debate sobre a História da Música Popular Brasileira nos últimos 35 anos do século $\mathrm{XX}^{1}$. O trabalho desse crítico e jornalista evidencia densidade analítica, que extrapola os limites da Imprensa periódica e retoma uma tradição clássica: fazer dialogarem o texto do cotidiano jornalístico - escrito dentro de severas condições de tempo e espaço editorial - com sua retaguarda analítica erudita, contribuindo para a ampliação desta. O cuidado informativo inclui bibliografia, iconografia e discografia, úteis para outros pesquisadores e demais interessados no tema - partituras enriqueceriam ainda mais tal amostragem.

O autor lança mão de debates próprios à Filosofia, Sociologia, Psicologia e Semiótica, demonstrando abrangência e desembaraço. Realiza, ainda, um esforço de História mediata ou do passado recente, comprovando a justeza da

\footnotetext{
* Retomo comunicação apresentada na mesa-redonda “A república do samba - Música, ritmo e cadência cariocas”, no XI Encontro Regional da ANPUH/RJ (UERJ, Rio de Janeiro, RJ), 22 de outubro de 2004. Agradeço a Raul Milliet, que me convidou para integrar a atividade.

${ }^{1}$ SANCHES, Pedro Alexandre. Decadência bonita do samba. São Paulo: Boitempo, 2000.
} 
tese de Jean Lacouture sobre esse gênero da escrita histórica como Jornalismo rigoroso ${ }^{2}$.

A tese central do livro: o samba - considerado o principal gênero musical popular autóctone brasileiro - sofreu grave decadência a partir dos ataques provenientes da produção tropicalista, especialmente, entre 1967 e 1969. Sanches situa, em meio a essa anunciada decadência, o esplendor de obrasprimas produzidas por alguns grandes sambistas contemporâneos do processo, como Chico Buarque e Paulinho da Viola, além da peculiar produção de Jorge Ben (Jor). A sedutora tese é defendida, na maior parte do tempo, com cerrada argumentação. Sua solidez se revela, em algumas passagens, também fragilidade ou camisa de força, quando renuncia a facetas de seu objeto para mais facilmente demonstrá-la.

Tal dificuldade se manifesta desde o capítulo inicial, “A voz do morto”, que toma título e base de seu principal argumento de empréstimo a uma canção homônima, de Caetano Veloso. Sanches é cuidadoso na reconstituição do contexto em que o samba foi composto e depois gravado, separadamente, pelo autor e pela sambista clássica Aracy de Almeida (citada, em fala atribuída a Rogério Duprat, na contra-capa do disco Tropicália ou panis et circensis: “com que olhos verão um jovem paulista nascido à época de Celly Campello e que desconhece Aracy \& Caymmi \& Cia?”). Mas finda deixando de lado uma dimensão polêmica da mesma canção: contra um congelamento cadaveroso, daquele gênero musical, pelas regras da Bienal do Samba, que a TV Record promoveu em 1968, um ataque a tópicos da poética tropicalista em nascimento e uma estratégia de mercado para combater os baianos, ligados, então, à TV Tupi e produzindo o programa “Divino, Maravilhoso”.

Seria muito acessível, para Sanches, o cartaz da Bienal, reproduzido na Imprensa da época. Ele apresenta John Lennon e Yoko Ono, de costas, nus, mais outros roqueiros estrangeiros, com uma legenda declarando querer ver as guitarras e aquele tipo de músicos pelas costas. A Record se irmanava aos argumentos repressivos da ditadura - roqueiros, hippies e usuários de drogas vistos como destruidores dos bons costumes e da família -, usando o argu-

\footnotetext{
${ }^{2}$ LACOUTURE, Jean. “A História imediata”. In: LE GOFF, Jacques (Org.). A História Nova. Tradução de Ana Maria Bessa. São Paulo: Martins Fontes, 1990, p. 215-240.
} 
mento da tradição do samba para esse fim. Revidar às justificativas ideológicas da Bienal (que se repetiu somente em 1971) não era - nem se desdobraria, necessariamente, em - lutar contra o samba em geral. Ao bradar "Viva o Paulinho da Viola!" (trecho interpretado por Sanches como "sarcasmo bélico”, p. 18), a canção nos lembrava que nem todo samba era declarado morto, que a morte rondava o samba de bienal, embora concorressem, naquele festival, canções de excepcional beleza, como "Coisas do mundo, minha nega", de Paulinho da Viola, “Bom tempo”, de Chico Buarque, e a vencedora "Lapinha”, de Baden Powell e Paulo César Pinheiro, mais alguns grandes sambas, de Cartola e outros... Nesse sentido, é necessário estabelecer diferenças entre o projeto ideológico da Record, argumentos ideológicos adotados por setores da música popular brasileira (compositores, intérpretes, críticos) e os sambas efetivamente ali apresentados, assim como o diálogo complexo do Tropicalismo com esse gênero. “Enquanto seu lobo não vem”, de Caetano Veloso, integrou o disco Tropicalismo ou Panis et Circensis e era um samba-enredo paródico e reflexivo.

Comentando, depois, a canção “A voz do vivo”, também de Veloso, gravada por Gilberto Gil, Sanches salienta o fascínio tropicalista por individualismo, tecnologia e viagens espaciais. Não aprofundou suas análises com a evocação de outras canções, no mesmo disco, que enfatizaram incomunicabilidade, tensões e desumanização nesse processo - "Cérebro eletrônico”, de Gil ("Só eu posso chorar, quando estou triste”); “2001”, de Tom Zé e Rita Lee (“Dei um grito no escuro / Sou parceiro do futuro / Na reluzente galáxia”); “Vitrines”, de Gil (“Sonhos guardados, perdidos / Em claros cofres de vidro”); "Futurível”, de Gil (“A felicidade é feita de metal”). O próprio tom tenso e até dissonante, na melodia e no arranjo de “A voz do vivo”, não é levado em conta. A lua e a rua, pontos de partida na letra dessa canção, menos que indiferença e negação de hierarquias na realidade, podem indicar a amplitude do real o próximo e o distante, o público e o, até então, inatingido.

Existem manifestações de samba em várias regiões do Brasil: samba de roda, em boa parte do litoral, samba rural paulista, samba mineiro, etc. Mas o modelo que se consolidou nacionalmente a partir dos anos 30 do século XX é, mais propriamente, carioca; com as contribuições milionárias de Bahia (desde antes, as tias baianas; na época referida, Dorival Caymmi, Assis Valente), Minas Gerais (Ary Barroso), Rio Grande do Sul (Lupicínio Rodrigues) e outras partes do país; modelo que foi divulgado pela indústria cultural nascente (gravadoras, emissoras de rádio), tendo por centro a então maior cidade brasileira e 
sede do governo federal, para o resto do território nacional, com o auxílio da ditadura estadonovista (1937/1945). Considerar o samba principal gênero musical autóctone do Brasil, como Sanches o faz, reforça um mito, que o Tropicalismo contribuiu para colocar em seu devido lugar: de mito.

A tese, todavia, está apoiada num importante referencial do projeto tropicalista: o descentramento da música popular em relação a um exclusivo modelo, realçando a pluralidade brasileira de tradições rítmicas, além dos laços internacionais que marcavam e marcam o formato da canção de mercado. Junto com sambas, marchas, toadas, baiões e outros gêneros tradicionais do cancioneiro nacional, Veloso, Gil, Mutantes, Tom Zé e Gal Costa gravaram ou compuseram, desde aquele início do Tropicalismo, rumbas, baladas, marchas sagradas ou cívicas, boleros, tangos, rocks, depois reggaes, funks, raps e outros ritmos. Isso não significou destruir o samba. Mas, certamente, realocou o gênero num painel mais amplo, nacional e cosmopolita. E talvez tenha resultado na morte do samba como gênero-rei - mas quem precisa de reis?

Sanches não discute, de forma mais detida, a canção de exílio "Aquele abraço", de Gil, como um bonito samba. Mesmo a bela "Desde que o samba é samba”, de Veloso, dos anos 90, teve realçadas apenas as dívidas, em relação a Paulinho da Viola, sem sublinhar que, afinal, constitui-se num exemplo da vitalidade que o gênero manteve, ao invés da alardeada decadência. Gal dedicou álbuns a Caymmi e Ary - cheios de sambas, como não poderia deixar de ser -, e anunciou um disco com repertório de Paulinho da Viola, que não gravou até hoje. Um roqueiro posterior ao Tropicalismo, Lobão, produziu belos sambas, caso do nietzscheano “Aurora”, e seu contemporâneo Cazuza regravou clássicos de Cartola e Nelson Cavaquinho.

Sanches apela para a noção de “neomedievalismo” (p. 23 do livro), reafirmando um entendimento de "Idade Média" como trevas e decadência. O conceito de “decadência”, antípoda e gêmea do progresso (ou "linha evolutiva”), é duvidoso porque dota a História de um sentido contínuo, alheio à ação concreta dos diferentes sujeitos. São conseqüências práticas de seu emprego considerar Gil e Veloso eternamente iguais a si mesmos e o samba como seguidor de uma trajetória inevitável de degradação (apesar das obras-primas), perdendo de vista nuanças nos processos históricos.

A expressão "linha evolutiva” ficou mais conhecida depois que foi usada por Augusto de Campos ${ }^{3}$. Antes dele, o conceito já se fizera presente em debates na Revista Civilização Brasileira, com a participação de Caetano Veloso e 
outros jovens músicos em ascensão. No disco Domingo, de Veloso e Gal Costa, o primeiro, escrevendo na contracapa, aborda a questão: “A minha inspiração não quer mais viver apenas da nostalgia de tempos e lugares, ao contrário, quer incorporar essa saudade num projeto de futuro”. No disco Tropicália, uma fala atribuída a Capinam descarta tanto tradição quanto linha evolutiva: "No Brasil e lá fora: nem ideologia nem futuro".

O autor também propõe a fixação de alta e baixa cultura, contra a equiparação de Veloso, Buarque e Gil a Villa-Lobos e Machado de Assis, “em arautos da intelectualidade, em símbolos nacionais” (p. 27). É sempre bom pensar sobre a produção efetiva de qualquer autor. A simples hierarquia entre alta e baixa cultura, todavia, pode mais confundir que explicar. Afinal, Machado e Dostoievski, dentre outros canônicos literatos, publicaram folhetins, e VillaLobos ia ouvir Ernesto Nazareth tocar em sala de cinema - alta ou baixa cultura? O cinema começou como "baixa cultura” e atingiu os patamares artísticos de Jean Renoir, Ingmar Bergman e Luchino Visconti. O crítico literário Antonio Cândido foi mais feliz, em entrevista para a revista Veja, ao encarar o trabalho de Chico Buarque como, simplesmente, cultura.

Sanches finda investindo mais na análise das letras de canções, como talentoso comentarista de metáforas e outros recursos verbais, sem desprezar arranjos, harmonias e melodias. Em algumas passagens, entretanto, excedese na dimensão ideológica dos versos, em benefício de sua tese central, perdendo de vista sutilezas... musicais!

É o caso de "Janelas abertas no 2", de Veloso. Sanches silencia a existência de uma anterior "Janelas abertas", de Tom Jobim e Vinicius de Morais. Esse detalhe nos remete a uma angustiada homenagem tropicalista à bossanova (“janelas abertas para o esplendor da paisagem, do novo e do amor”, em Jobim/Morais) e ao anúncio da existência, naquele trágico momento - escalada da ditadura -, de outras janelas, que substituíam as portas e autorizavam a invasão de apartamento, corpo e ser pelos insetos.

\footnotetext{
${ }^{3}$ CAMPOS, Augusto de. Balanço da bossa e outras bossas. São Paulo: Perspectiva, 1974
} (Debates - 22). $1^{\text {a }}$ ed., 1969. 
A análise realça um percurso de interiorização, sugerindo desprezo do compositor pelo mundo exterior. Deixa de observar, todavia, como a música é uma tensa visão dessa interiorização (toda a letra se organiza em relação a “eu poderia abrir as portas que dão p’ra dentro”, mas a opção final é “abrir as janelas / p'ra que entrem / todos os insetos" - o interior ocupado lateralmente pelo que vem de fora). Ao invés de se interiorizar, o eu poético - que pode ser personagem e não se confunde com o cidadão autor, como ensinou Fernando Pessoa - anuncia o mundo dos insetos, que o invade (como vermes em relação aos cadáveres, mas de forma permitida): “Até que a plenitude e a morte coincidissem um dia / O que aconteceria de qualquer jeito”.

A canção surgiu em plena ditadura, com o compositor já exilado (Maria Bethânia a lançou, junto com “Mano Caetano”, de Jorge Ben, no disco Presença morena). Contra a hipótese da pura interiorização, cabe pensar no ato de apresentar um mundo ameaçador, de insetos, do qual não se foge - o país não se militarizou apenas por obra dos militares, houve uma invasão, permitida também pelos civis, na mínima democracia antes existente. Estamos diante de uma fábula de horror. De passagem, o mito de interioridade versus exterioridade, se esvai. E tudo isso cantado com o belo excesso dramático de Maria Bethânia, num de seus grandes momentos - Chico Buarque, no show que depois fez com Veloso, nos anos 70, e foi transformado em disco, interpretou a canção num registro ainda mais triste.

Os argumentos de Sanches são, quase sempre, minuciosos, deixando de lado, todavia, detalhes significativos das canções: o tom festivo de "Soy loco por ti América”, de Gilberto Gil, Capinam e Torquato Neto (apesar das ditaduras e de "El nombre del hombre muerto”); a duração de “Clarice”, de Caetano (fora dos parâmetros habituais de canção feita para tocar no rádio); o refinado arranjo operístico, de Rogério Duprat, para “Coração materno”, original de Vicente Celestino, regravada por Veloso no disco Tropicália; a forte presença do paródico, nessa etapa inicial do Tropicalismo, sua relação de comentário crítico de múltiplos gêneros e ritmos musicais.

Num plano mais geral, o crítico realça especialmente o papel de Glauber Rocha e do filme Terra em transe, de 1966, na gênese do Tropicalismo, pela fusão simultânea de vários tempos de Brasil, diferente do otimismo desenvolvimentista e moderno. Um segundo tijolo no edifício tropicalista é representado pela montagem de $O$ rei da vela, texto de Oswald de Andrade, dirigido por José Celso Martinez Corrêa, em 1967. Essas evocações de duas 
importantes tradições de esquerda como bases do Tropicalismo poderiam ser ainda mais ampliadas pelo registro da participação de Veloso e Gil na Feira Paulista de Opinião (1967, promovida pelo Teatro Opinião de São Paulo), o primeiro com “Mãe coragem”, o outro com “Misere nobis”. As duas canções, depois, seriam incluídas no disco-manifesto Tropicália ou Panis et Circensis.

Falando sobre “Mãe coragem”, Sanches destaca a separação mãe sofrida/ filho cruel, sem identificar uma clara crueldade materna - "Ser mãe é desdobrar, fibra por fibra, o coração dos filhos”. Referindo-se a "Cultura e civilização”, de Gil, o crítico assume, literalmente, uma oposição do título a "licor de jenipapo” (p. 83). Uma astúcia poética da letra, entretanto, pode se ampliar o repertório desses conceitos solenes: além do licor, “cabelo belo”, "ficar na minha”, “comer com coentro”... E em "Refazenda”, também de Gil, salienta "escapismo” (p. 92), sem explorar o clima fabular de transformação possível, de uma coisa vindo a ser outra - talvez história.

E em meio às análises, o inteligente escritor se torna retro-conselheiro dos ditadores, para afirmar: "o niilismo despriorizante que [os tropicalistas] propagavam se revelara, aos olhos e ouvidos dos militares, nocivo aos propósitos do regime - que, desastrado que era, não percebeu que a tropicália, em termos, não deixava de se afinar com seus propósitos imobilizadores” (p. 71). Com certeza, Sanches não é um tardo-admirador daquela ditadura, mas seu argumento resvala perigosamente para o campo de identificar os reais interesses dos desastrados opressores. Um caminho alternativo a esse seria procurar entender o que tanto incomodou os ditadores no universo tropicalista: liberdade paródica, incerteza em relação ao passado e futuro, descrença no tempo único do progresso? Sem esquecer de citações distorcidas da melodia do Hino Nacional, em arranjos do disco Tropicália (“Geléia geral”, talvez "Parque industrial”) e dos disparos de canhão encerrando "Misere nobis”, abrindo "Coração materno" e fechando o "Hino ao Senhor do Bomfim", junto com a passeata, “debaixo das botas, das bandeiras”, de "Enquanto seu lobo não vem”: Chapeuzinho Vermelho não era tolinha!

Comentando a produção pós-tropicalista desse mesmo grupo, Sanches reitera os temas pós-modernidade e fim da história. Perde de vista, aparentemente, os significados de canções para o universo social, reduzindo-as a trajetos individuais de seus autores e ao imediato ideológico. É assim que a letra de “Oração ao tempo", de Caetano, se vê reduzida a "submissão da existência exterior à individualidade do artista pós-moderno”, sem levar em conta a clás- 
sica tensão metafísica entre finito e infinito. E a letra de "Uns", do mesmo compositor, é interpretada no singular: “Tudo é um” (p. 145).

Uma grande qualidade de Tropicalismo - Decadência bonita do samba é comentar tanto os trajetos de Caetano e Gil quanto as produções de alguns de seus contemporâneos e interlocutores musicais, como Chico Buarque, Paulinho da Viola e Jorge Ben (Jor). A etapa conclusiva do livro, no capítulo "Rios, pontes e overdrives”, estabelece nuances em relação à tese central do samba em decadência, enfatizando a importância central desse gênero no disco “Tropicália II”, de Gil e Caetano, lançado em 1997. O sentido único do livro, portanto, é redirecionado potencialmente, assumindo, que, afinal, o samba acabou "só se foi quando o dia clareou” (Paulinho da Viola, “Eu canto samba”). 